\title{
Inhibitory Effect of Lignans from Myristica fragrans on LPS-induced NO Production in RAW264.7 Cells
}

\author{
Byung Sun Min," To Dao Cuong, Tran Manh Hung, Bo Kyung Min, Bum Soo Shin, and Mi Hee Woo \\ College of Pharmacy, Catholic University of Daegu, Gyeongsan, Gyeongbuk 712-702, Korea \\ *E-mail:bsmin@cu.ac.kr
}

Received July 11, 2011, Accepted September 2, 2011

Key Words : Myristica fragrans, Myristicaceae, Lignan, Anti-inflammatory activity

Inflammation is a beneficial host response to foreign challenge or tissue injury that leads ultimately to the restoration of tissue structure and function. ${ }^{1}$ Inflammation involves a complex web of intercellular cytokine signals. Activated monocytes and/or macrophages release a variety of inflammatory mediators, such as tumor necrosis factor- $\alpha$ (TNF- $\alpha$ ) and interleukin-1 $\beta$ (IL-1 $\beta$ ), reactive oxygen species, prostaglandin E2 (PGE2) and nitric oxide (NO). ${ }^{2}$ A normal inflammatory response is self-limiting and involves the down-regulation of pro-inflammatory protein expression, increased expression of anti-inflammatory proteins and a reversal in the vascular changes that facilitated the initial immune cell recruitment process. ${ }^{3}$ Nitric oxide (NO) is a short-living free radical that is produced from L-arginine by catalytic reaction of NO synthases (NOSs) within mammalian immune, cardiovascular and neural systems, where it functions as a signaling or cytotoxic molecule. ${ }^{4}$ Cyclooxygenase $(\mathrm{COX})$, an enzyme also known as prostaglandin (PG) $\mathrm{H}$ synthase (EC 1.14.99.1), converts arachidonic acid to prostaglandins, which play a crucial role as mediators of inflammatory responses. ${ }^{5}$

Myristica fragrans Houtt (Myristicaceae) is an aromatic evergreen tree cultivated in South Africa India, and other

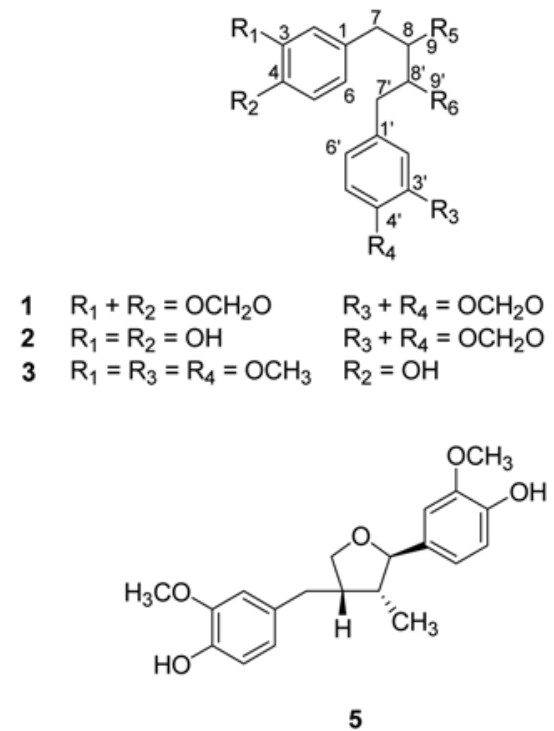

tropical countries. The seed and aril of the fruit of $M$. fragrans are commonly known as nutmeg and mace, respectively. Since the Middle Ages, nutmeg has been used as a carminative, stimulant, narcotic, emmenagogue and abortifacient. ${ }^{6}$ Nutmeg is also prescribed for medicinal purposes in Asia to treat many diseases, such as rheumatism, muscle spasm, decreased appetite and diarrhea. ${ }^{7}$ It has shown antioxidant, anti-inflammatory, ${ }^{8}$ protein tyrosine phosphatase 1B inhibitory, ${ }^{9}$ hepatoprotective ${ }^{10}$ and acetylcholine esterase inhibitory activities. $^{11}$ In continuing investigation for discovering inhibitors on LPS-induced NO production in macrophage RAW264.7 cells, studies of the EtOAc-soluble fraction from the seeds of $M$. fragrans resulted in the isolation of a new lignan (1), along with five known ones (2-6). This paper describes the isolation and structural elucidation of the isolates, as well as the evaluation of their inhibitory activity on LPS-induced NO production in macrophage RAW264.7 cells.

The $\mathrm{MeOH}$ extract of the seeds of $M$. fragrans was partitioned into hexane-, EtOAc- and $n-\mathrm{BuOH}$-soluble fractions. Chromatographic purification of the ethyl acetate fraction led to the isolation of six compounds (1-6) (Fig. 1). The structures of known compounds were identified as $\left(8 R, 8^{\prime} S\right)$ -<smiles>COc1cc([C@H]2c3cc(O)c(OC)cc3C[C@@H](C)[C@@H]2C)ccc1O</smiles>

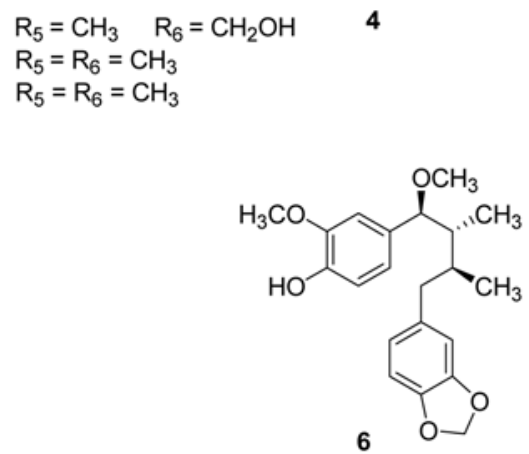

$\mathrm{R}_{5}=\mathrm{R}_{6}=\mathrm{CH}_{3}$

Figure 1. Chemical Structures of Isolated Compounds (1-6). 
7'-(3',4'-methylenedioxyphenyl)-8,8'-dimethyl-7-(3,4-dihydroxyphenyl)-butane (2), meso-monomethyldihydroguaiaretic acid (3), (+)-guaiacin (4), (7S,8'R,7'R)-4,4'-dihydroxy-3,3'dimethoxy-7',9-epoxylignan (5), 7-(4-hydroxy-3-methoxyphenyl)-7-(3,4-methylenedioxyphenyl)-8,8-lignan-7-methyl ether (6) by comparing their physical and spectroscopic data with previous reported papers. ${ }^{12-16}$

Compound 1 was isolated as colorless oil, with the molecular formula $\mathrm{C}_{20} \mathrm{H}_{22} \mathrm{O}_{5}$, as determined by the HR-TOF-MS at $m / z 343.1541$ for the $[\mathrm{M}+\mathrm{H}]^{+}$ion (calcd for $\mathrm{C}_{20} \mathrm{H}_{23} \mathrm{O}_{5}$, $343.1545)$. Its optical rotation had a value of +12.5 and the UV spectrum exhibited its $\lambda_{\max }$ at $286 \mathrm{~nm}(\mathrm{MeOH})$. The ${ }^{1} \mathrm{H}-$ NMR spectrum showed two ortho-coupled aromatic protons at $\delta_{\mathrm{H}} 6.69(\mathrm{H}-5), 6.57(\mathrm{H}-6), 6.67\left(\mathrm{H}^{-5}\right)$ and $6.88\left(\mathrm{H}-6^{\prime}\right)$, two singlet aromatic protons at $\delta_{\mathrm{H}} 6.58(\mathrm{H}-2)$, and $6.51\left(\mathrm{H}-2^{\prime}\right)$, two methine protons at $\delta_{\mathrm{H}} 1.87(\mathrm{H}-8)$, and $1.75\left(\mathrm{H}-8^{\prime}\right)$, six methylene protons, two methylenedioxy protons at $\delta_{\mathrm{H}} 5.89$ $\left(3,4-\mathrm{OCH}_{2} \mathrm{O}\right)$ and $5.87\left(3^{\prime}, 4^{\prime}-\mathrm{OCH}_{2} \mathrm{O}\right)$, and one methyl proton at $\delta_{\mathrm{H}} 0.87(\mathrm{H}-9)$ (Table 1$)$. The ${ }^{13} \mathrm{C}-\mathrm{NMR}$ data with DEPT experiments of 1 showed the presence of 20 carbon atoms including twelve aromatic carbons, three methylene carbons, two methine carbon signals at $\delta_{\mathrm{C}} 35.9(\mathrm{C}-8)$ and $47.5\left(\mathrm{C}-8^{\prime}\right)$, and two methylenedioxy carbon at $\delta_{\mathrm{C}} 102.2$ $\left(3,4-\mathrm{OCH}_{2} \mathrm{O}\right)$ and $102.0\left(3^{\prime}, 4^{\prime}-\mathrm{OCH}_{2} \mathrm{O}\right)$ (Table 1). The ${ }^{1} \mathrm{H}-$ and ${ }^{13} \mathrm{C}$-NMR spectra of $\mathbf{1}$ were very similar to those of austrobailignan-5, which was isolated from Saururus cernunus. ${ }^{17}$ However, the ${ }^{1} \mathrm{H}$ and ${ }^{13} \mathrm{C}$ NMR spectra showed a hydroxymethyl signal, which was confirmed by the HMBC correlations between two methine protons at $\delta_{\mathrm{H}} 1.87(\mathrm{H}-8) /$

Table 1. ${ }^{1} \mathrm{H}$ NMR and ${ }^{13} \mathrm{C}$ NMR Spectroscopic Data of Compound

\begin{tabular}{llll}
\hline Position & $\delta_{\mathrm{H}}(\mathrm{ppm})$ & $\delta_{\mathrm{C}}(\mathrm{ppm})$ & \multicolumn{1}{c}{ HMBC } \\
\hline 1 & & 136.7 & \\
2 & $6.58(\mathrm{~s})$ & 110.4 & $\mathrm{C}-7, \mathrm{C}-1, \mathrm{C}-3, \mathrm{C}-4, \mathrm{C}-6$ \\
3 & & 149.1 & \\
4 & & 149.0 & \\
5 & $6.69(\mathrm{~d}, 8.8)$ & 108.9 & $\mathrm{C}-1, \mathrm{C}-3, \mathrm{C}-4, \mathrm{C}-6$ \\
6 & $6.57(\mathrm{~d}, 8.8)$ & 123.1 & $\mathrm{C}-7, \mathrm{C}-1, \mathrm{C}-2, \mathrm{C}-4, \mathrm{C}-5$ \\
7 & $2.65(\mathrm{dd}, 6.8,14.4)$ & 41.5 & $\mathrm{C}-8^{\prime}, \mathrm{C}-8, \mathrm{C}-1, \mathrm{C}-2, \mathrm{C}-6$, \\
& $2.35(\mathrm{dd}, 8.8,14.4)$ & & $\mathrm{C}-9$ \\
8 & $1.87(\mathrm{~m})$ & 35.9 & $\mathrm{C}-7^{\prime}, \mathrm{C}-8^{\prime}, \mathrm{C}-7, \mathrm{C}-9, \mathrm{C}-9^{\prime}$ \\
9 & $0.87(\mathrm{~d}, 7.2)$ & 15.8 & $\mathrm{C}-7, \mathrm{C}-8, \mathrm{C}-8^{\prime}$ \\
$1^{\prime}$ & & 136.5 & \\
$2^{\prime}$ & $6.51(\mathrm{~s})$ & 110.2 & $\mathrm{C}-7^{\prime}, \mathrm{C}-1^{\prime}, \mathrm{C}-3^{\prime}, \mathrm{C}-4^{\prime}, \mathrm{C}-6^{\prime}$ \\
$3^{\prime}$ & & 147.2 & \\
$4^{\prime}$ & & 147.1 & \\
$5^{\prime}$ & $6.67(\mathrm{~d}, 8.4)$ & 108.8 & $\mathrm{C}-1^{\prime}, \mathrm{C}-3^{\prime}, \mathrm{C}-4^{\prime}, \mathrm{C}-6^{\prime}$ \\
$6^{\prime}$ & $6.88(\mathrm{~d}, 8.4)$ & 123.0 & $\mathrm{C}-7^{\prime}, \mathrm{C}-1^{\prime}, \mathrm{C}-2^{\prime}, \mathrm{C}-4^{\prime}, \mathrm{C}-5^{\prime}$ \\
$7^{\prime}$ & $2.65(\mathrm{dd}, 6.8,14.4)$ & 35.9 & $\mathrm{C}-1^{\prime}, \mathrm{C}-2^{\prime}, \mathrm{C}-6^{\prime}, \mathrm{C}-8^{\prime}, \mathrm{C}-8$ \\
& $2.48(\mathrm{dd}, 8.0,14.4)$ & & \\
$8^{\prime}$ & $1.75(\mathrm{~m})$ & 47.5 & $\mathrm{C}-7^{\prime}, \mathrm{C}-8, \mathrm{C}-7, \mathrm{C}-9, \mathrm{C}-9^{\prime}$ \\
$9^{\prime}$ & $3.66(\mathrm{dd}, 5.6,10.8)$ & 62.7 & $\mathrm{C}^{\prime} 7^{\prime}, \mathrm{C}-8, \mathrm{C}-8^{\prime}$ \\
& $3.46(\mathrm{dd}, 6.8,10.8)$ & & \\
$3,4-\mathrm{OCH}_{2} \mathrm{O}$ & $5.89(\mathrm{~s})$ & 102.2 & $\mathrm{C}-3, \mathrm{C}-4$ \\
$3^{\prime}, 4^{\prime}-\mathrm{OCH}_{2} \mathrm{O}$ & $5.87(\mathrm{~s})$ & 102.0 & $\mathrm{C}-3^{\prime}, \mathrm{C}-4^{\prime}$ \\
\hline & & &
\end{tabular}

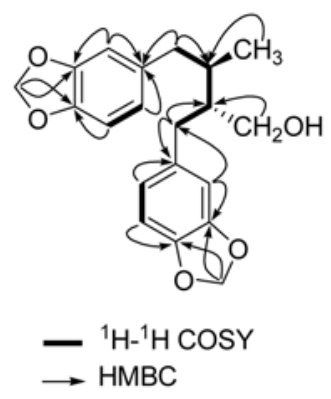

Figure 2. Selected ${ }^{1} \mathrm{H}-{ }^{1} \mathrm{H}$ COSY and HMBC Correlations $(\mathrm{H} \rightarrow \mathrm{C})$ for new Compound (1).

$1.75\left(\mathrm{H}-8^{\prime}\right)$ and $\delta_{\mathrm{C}} 62.7\left(\mathrm{C}-9^{\prime}\right)$. Furthermore, the long-range correlations between two methylene protons at $\delta_{\mathrm{H}} 2.65$ and 2.48 and $\delta_{\mathrm{C}} 62.7$ (C-9') also were observed, suggesting that the hydroxymethyl group was located at the C-9' position (Fig. 2). The positive optical rotation $\left([\alpha]_{\mathrm{D}}^{25}+12.5\right)$ for $\mathbf{1}$, being the same as that of macelignan $\left([\alpha]_{\mathrm{D}}^{20}+5.28\right)$, also isolated from $M$. fragrans, hinted that $\mathbf{1}$ probably shared the $[R, S]$ configuration of macelignan, ${ }^{18}$ which was further confirmed by comparison with the ${ }^{13} \mathrm{C}$ NMR spectrum at [C-8' $\left(\delta_{\mathrm{C}} 47.5\right)$, and C-9' $\left.\left(\delta_{\mathrm{C}} 62.7\right)\right]$ of 1 and that of secoisolariciresinol [C-8' $\left(\delta_{\mathrm{C}} 43.7\right)$, and C-9' $\left.\left(\delta_{\mathrm{C}} 60.5\right)\right] .{ }^{19}$ Based on the above data analyses, compound 1 was established to be $(8 R, 8$ 'S)-7-(3,4-methylenedioxyphenyl)-8methyl-8'-hydroxymethyl-7'-(3',4'-methylenedioxyphenyl)butanol.

The cytotoxic effects of the isolated compounds (1-6) were evaluated in the presence or absence of LPS using the MTT assay. These compounds did not affect the cell viabilities of RAW 264.7 cells in either the presence or absence of LPS, even at a dose of $50 \mu \mathrm{M}$ after a period of $24 \mathrm{~h}$ (data not shown). The amount of NO produced was determined by the amount of nitrite, a stable metabolite of NO. To assess the effects of these compounds on the LPS-induced production of NO in RAW 264.7 cells, a cell culture medium was harvested, with the production of nitrite measured using the Griess reaction. As shown in Table 2, compound 1-3, 5-6 showed inhibitory potency, with $\mathrm{IC}_{50}$ value of $45.4,3.4$, 26.1, 26.5 and $33.5 \mu \mathrm{M}$, respectively, while compound 4

Table 2. Inhibition of NO Production in Macrophage RAW264.7 Cells by Compounds $\mathbf{1 6}$

\begin{tabular}{cc}
\hline Compound & $\mathrm{IC}_{50}$ value $(\mu \mathrm{M})^{a}$ \\
\hline $\mathbf{1}$ & $45.4 \pm 2.3$ \\
$\mathbf{2}$ & $3.4 \pm 0.3$ \\
$\mathbf{3}$ & $26.1 \pm 2.6$ \\
$\mathbf{4}$ & $>50$ \\
$\mathbf{5}$ & $26.5 \pm 2.1$ \\
$\mathbf{6}$ & $33.5 \pm 4.1$ \\
Celastrol $^{b}$ & $1.0 \pm 0.1$ \\
\hline
\end{tabular}

${ }^{a}$ The inhibitory effects are represented as the molar concentration $(\mu \mathrm{M})$ giving $50 \%$ inhibition $\left(\mathrm{IC}_{50}\right)$ relative to the vehicle control. These data represent the average values of three repeated experiments. ${ }^{b}$ Positive control for NO production. 


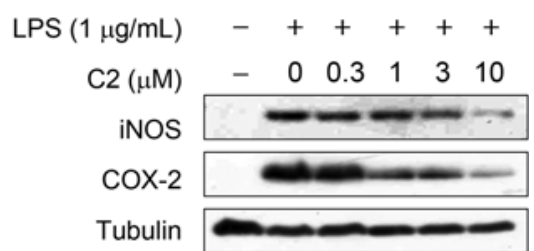

Figure 3. Inhibition of LPS-induced iNOS and COX-2 Expression in RAW264.7 Cells by Compound 2 (C2). RAW264.7 cells were pretreated for $30 \mathrm{~min}$ with the indicated concentrations of $\mathbf{2}$, and followed by the stimulation with LPS $(1 \mu \mathrm{g} / \mathrm{mL})$ for $18 \mathrm{~h}$. Total lysates were prepared and the expression levels of iNOS and COX2 were determined by immunoblot analysis. Histograms show densitometric analyses of relative iNOS and COX-2 expression levels normalised against $\alpha$-tubulin. bar., the mean \pm S.D. Asterisk indicates a significant difference $(* *, \mathrm{P}<0.01)$ compared the control.

was inactive up to the $50 \mu \mathrm{M}$ level. Since compound 2 exhibited a strong inhibitory effect on the LPS-induced production of NO in macrophage RAW264.7 cells, the effect of this compound on the LPS-induced COX-2 and iNOS expressions were investigated. RAW264.7 cells were stimulated with $1 \mu \mathrm{g} / \mathrm{mL}$ of LPS for $18 \mathrm{~h}$ in the presence of increasing concentrations of $\mathbf{2}$, and the expression levels of COX-2 and iNOS protein were determined by immunoblot analyses (Fig. 3). Compound $2(0-10 \mu \mathrm{M})$ dose-dependently reduced the LPS-induced COX-2 and iNOS expressions, but did not change that of $\alpha$-tubulin. The results showed that 2 inhibited not only the iNOS and COX-2 mRNA expressions, but also the iNOS and COX-2 promoter activities in LPS stimulated RAW264.7 cells, suggesting that this compound could suppress LPS-induced iNOS and COX-2 expressions at the transcription level.

\section{Experimental}

General Experimental Procedure. Optical rotations were measured with a JASCO DIP 370 digital polarimeter. UV spectra were taken in $\mathrm{MeOH}$ using a Thermo spectrometer, and IR spectra were obtained on a JASCO FT/IR4100 spectrometer. The nuclear magnetic resonance (NMR) spectra were obtained on Varian Unity Inova $400 \mathrm{MHz}$ spectrometer. Silica gel (Merck, 63-200 $\mu \mathrm{m}$ particle size), ODS-A (YMC, $150 \mu \mathrm{m}$ particle size) were used for column chromatography. TLC was carried out using Merck silica gel $60 \mathrm{~F}_{254}$ and RP-18 $\mathrm{F}_{254}$ plates. HPLC was carried out using a Water system with a UV detector and an YMC Pak ODS-A column $(20 \times 250 \mathrm{~mm}, 5 \mu \mathrm{m}$ particle size, YMC Co., Ltd., Japan) and HPLC solvents were from Burdick \& Jackson, USA.

Plant Material. The seeds of $M$. fragrans were purchased in Dong Xuan herbarium market, Hanoi, Vietnam, in January 2010 and identified by Professor Pham Thanh Ky, Department of Pharmacognosy, Hanoi University of Pharmacy. A voucher specimen (0182) was deposited in the herbarium of the Hanoi College of Pharmacy.

Extraction and Isolation. The seeds of M. fragrans (2 $\mathrm{kg}$ ) were extracted three times $(3 \mathrm{~h} \times 3 \mathrm{~L})$ with refluxing methanol. After the solvent was removed under reduced pressure, the residue was suspended in $\mathrm{H}_{2} \mathrm{O}$ and then partitioned with $n$-hexane, EtOAc, and $n$-BuOH, successively. The EtOAc soluble fraction $(54 \mathrm{~g})$ was chromatographic on a silica gel column $(10 \times 60 \mathrm{~cm} ; 63-200 \mu \mathrm{m}$ particle size, Merck) using a stepwise gradient of $\mathrm{CHCl}_{3}: \mathrm{MeOH}(50: 1$ to $0: 1$, each $2 \mathrm{~L})$ to yield nine fractions (Fr.1-Fr.9) according to their TLC profiles. Fraction $4(1.2 \mathrm{~g})$ was subjected to reversed phase (ODS-A) column chromatography $(6.0 \times 60 \mathrm{~cm} ; 150 \mu \mathrm{m}$ particle size) and eluted with $\mathrm{MeOH} / \mathrm{H}_{2} \mathrm{O}$ (from 4:1 to 1:0, 3 L for each step) to afford four sub-fractions (Fr.4-1 to Fr.44). Further purification of Fr.4-2 (350 mg) by semi-preparative Waters HPLC systems [using an isocratic solvent system of $75 \% \mathrm{MeOH}$ in $\mathrm{H}_{2} \mathrm{O}+0.1 \%$ trifluoroacetic acid (flow rate $5 \mathrm{~mL} / \mathrm{min}$ ) over $90 \mathrm{~min}$; UV detection at $210 \mathrm{~nm}$; YMC Pak ODS-A column $(20 \times 250 \mathrm{~mm}, 5 \mu \mathrm{m}$ particle size)] resulted in the isolation of compound $4\left(44 \mathrm{mg} ; t_{\mathrm{R}}=\right.$ $42.5 \mathrm{~min}$ ). Fraction 7 (3.2 g) was also subjected to reversed phase (ODS-A) column chromatography $(6.0 \times 60 \mathrm{~cm} ; 150$ $\mu$ m particle size) and eluted with $\mathrm{MeOH} / \mathrm{H}_{2} \mathrm{O}$ (from 5:2 to 1:0, $2 \mathrm{~L}$ for each step) to afford five sub-fractions (Fr.7-1 to Fr.7-5). Further purification of Fr.7-3 (610 mg) by semipreparative Waters HPLC systems [using an isocratic solvent system of $70 \% \mathrm{MeOH}$ in $\mathrm{H}_{2} \mathrm{O}+0.1 \%$ trifluoroacetic acid (flow rate $5 \mathrm{~mL} / \mathrm{min}$ ) over $90 \mathrm{~min}$; UV detection at 210 $\mathrm{nm}$; YMC Pak ODS-A column $(20 \times 250 \mathrm{~mm}, 5 \mu \mathrm{m}$ particle size)] resulted in the isolation of compounds $1\left(14.5 \mathrm{mg} ; t_{\mathrm{R}}=\right.$ $44.8 \mathrm{~min}), 2\left(14.5 \mathrm{mg}, t_{\mathrm{R}}=39.2 \mathrm{~min}\right)$, and $\mathbf{3}\left(23.3 \mathrm{mg}, t_{\mathrm{R}}=\right.$ $49.2 \mathrm{~min})$, respectively. Sub-fraction F.7-4 $(359 \mathrm{mg}$ ) was further purified by semi preparative HPLC [using an isocratic solvent system of $75 \% \mathrm{MeOH}$ in $\mathrm{H}_{2} \mathrm{O}+0.1 \%$ trifluoroacetic acid (flow rate $5 \mathrm{~mL} / \mathrm{min}$ ) over $90 \mathrm{~min}$; UV detection at $210 \mathrm{~nm}$; YMC Pak ODS-A column $(20 \times 250$ $\mathrm{mm}, 5 \mu \mathrm{m}$ particle size)] resulted in the isolation of compounds $5\left(19.5 \mathrm{mg}, t_{\mathrm{R}}=41.2 \mathrm{~min}\right)$ and $\mathbf{6}\left(21.2 \mathrm{mg}, t_{\mathrm{R}}=45.3 \mathrm{~min}\right)$, respectively.

(8R,8'S)-7-(3,4-methylenedioxyphenyl)-8-methyl-8'-hydroxymethyl-7'-(3',4'-methylenedioxyphenyl)-butanol (1): colorless oil; $[\alpha]_{\mathrm{D}}^{25}+12.5(c=0.12, \mathrm{MeOH})$; UV $\lambda_{\max }$ (MeOH): $286 \mathrm{~nm}$; HR-TOF-MS $m / z 343.1541[\mathrm{M}+\mathrm{H}]^{+}$ (calcd for $\left.\mathrm{C}_{20} \mathrm{H}_{23} \mathrm{O}_{5}, 343.1545\right)$; $\mathrm{CD}(c \mathrm{0} 0.1, \mathrm{MeOH}): \Delta \varepsilon_{207}$ $+5.10, \Delta \varepsilon_{234}-1.79 ;{ }^{1} \mathrm{H}$ NMR $\left(400 \mathrm{MHz}, \mathrm{CD}_{3} \mathrm{OD}\right)$ and ${ }^{13} \mathrm{C}$ NMR (100 MHz, $\left.\mathrm{CD}_{3} \mathrm{OD}\right)$ spectroscopic data, see Table 1.

Cell Culture. RAW264.7 cells were maintained in Dulbecco's Modified Essential Medium supplemented with penicillin (100 units $/ \mathrm{mL})$, streptomycin $(100 \mu \mathrm{g} / \mathrm{mL})$ and $10 \%$ heat-inactivated fetal bovine serum.

Determination of NO Production and the Cell Viability Assay. The level of NO production was determined by measuring the amount of nitric from the cell culture supernatants as described previously. Briefly, the RAW264.7 cells (ATCC, Rockville, MD, USA, $1 \times 10^{5}$ cells/well) were stimulated with or without $1 \mu \mathrm{g} / \mathrm{mL}$ of LPS (Sigma Chemical Co., St. Louis, MO) for $24 \mathrm{~h}$ in the presence or absence of the test compounds $(0.5-25 \mu \mathrm{M})$. The cell culture supernatant $(100 \mu \mathrm{L})$ was then reacted with $100 \mu \mathrm{L}$ of Griess reagent. The remaining cells after the Griess assay were used 
to test their viability using a MTT (Sigma Chemical Co., St. Louis, MO)-based colorimetric assay as previously described. ${ }^{20}$ Celastrol was used as the positive control.

Immunoblot Analysis. Proteins were extracted from cells in ice-cold lysis buffer (50 mM Tris- $\mathrm{HCl}, \mathrm{pH} 7.5,1 \%$ Nonidet P-40, $1 \mathrm{mM}$ EDTA, $1 \mathrm{mM}$ phenylmethyl sulfonyl fluoride, $1 \mu \mathrm{g} / \mathrm{mL}$ leupeptin, $1 \mathrm{mM}$ sodium vanadate, 150 $\mathrm{mM} \mathrm{NaCl}$ ). Fifty $\mu \mathrm{g}$ of protein per lane was separated by sodium dodecyl sulfate (SDS)-polyacrylamide gel electrophoresis (PAGE) and followed by transferring to a polyvinylidene difluoride membrane (Millipore, Bedford, MA, USA). The membrane was blocked with 5\% skim milk, and then incubated with the corresponding antibody. Antibodies for COX-2, iNOS were obtained from Santa Cruz Biotechnology (Santa Cruz, CA, USA). Antibody for $\alpha$-tubulin was from Sigma. After binding of an appropriate secondary antibody coupled to horseradish peroxidase, proteins were visualized by enhanced chemiluminescence according to the instructions of the manufacturer (Amersham Pharmacia Biotec, Buckinghamshire, UK).

Acknowledgments. This research was supported by research grants from Catholic University of Daegu in 2011.

\section{References and Notes}

1. Majno, G. Harvard. Univ. Pres., Cambridge 1975.

2. Larsen, G. L.; Henson, P. M. Annu. Rev. Immunol. 1983, 1, 335.
3. Han, J.; Ulevitch, R. J. Nat. Immunol. 2005, 6, 1198.

4. Nathan, C.; Xie, Q. W. J. Biol. Chem. 1994, 269, 13725.

5. Fu, J. Y.; Masferrer, J. L.; Seibert, K.; Raz, A.; Needleman, P. J. Biol. Chem. 1990, 265, 16737.

6. Hall, R. L. Nat. Acad. Sci. 1973, 448

7. Barnes, J.; Anderson, L. A.; Phillipson, J. D. Pharmaceu. Press London. 2007, 136.

8. Ritter, R.; Schatton, W. F. H.; Gessner, B.; Willems, M. Complement. Ther. Med. 1993, 1, 189.

9. Lee, J.; Shon, M. Y.; Jang, D. S.; Ha, T. J.; Hwang, S. W.; Nam, S. H.; Seo, E. K.; Park, K. H.; Yang, M. S. Agric. Chem. Biotechnol. $\mathbf{2 0 0 5}, 48,198$

10. Kim, D. K.; Lee, K. T.; Baek, N. I.; Kim, S. H.; Park, H. W.; Lim, J. P.; Shin, T. Y.; Eom, D. O.; Yang, J. H.; Eun, J. S. Arch. Pharm. Res. 2004, 27, 1127.

11. Matthew, J.; Fleming, H. A.; McManus, A. R.; Chan, W. H.; Ruiz, J.; Dockendorff, C.; Lautens, M. Chem. Eur. J. 2008, 14, 2112.

12. Cavalcante, S. H.; Yoshida, M.; Gottlieb, O. R. Phytochemistry 1985, 24, 1051.

13. Rao, K. V.; Chattopadhyay, S. K. J. Org. Chem. 1990, 55, 1427.

14. Miyazawa, M.; Asahara, H.; Ameoka, H. Phytochemistry 1997, 46, 1173.

15. Yang, G.; Xu, Y.; Chen, Y.; Li, G.; Li, Zhong. Faming Zhuanli Shenqing 2010; p 12.

16. Kwon, H. S.; Kim, M. J.; Jeong, H. J.; Yang, M. S.; Park, K. H.; Jeong, T. S.; Lee, W. S. Bio. Med. Chem. Lett. 2008, 18, 194.

17. Rao, K. V.; Alvarez, F. M. J. Nat. Prod. 1982, 45, 393.

18. Woo, W. S.; Shin, K. H.; Wagner, H.; Lotter, H. Phytochemistry 1987, 26, 1542.

19. Fonseca, S. F.; Campeelo, J. P.; Barata, L. E. S.; Rúveda, E. A. Phytochemistry 1987, 17, 499.

20. Lee, J.; Tae, N.; Lee, J. J.; Kim, T.; Lee, J. H. Eur. J. Pharmacol. 2010, 636, 173. 